\title{
Auxiliary activation of the complement system and its importance for the pathophysiology of clinical conditions
}

\author{
Markus Huber-Lang ${ }^{1}$ - Kristina N. Ekdahl ${ }^{2,3} \cdot$ Rebecca Wiegner $^{1} \cdot$ Karin Fromell $^{2}$. \\ Bo Nilsson ${ }^{2}$
}

Received: 11 May 2017 / Accepted: 3 August 2017 / Published online: 12 September 2017

(C) The Author(s) 2017. This article is an open access publication

\begin{abstract}
Activation and regulation of the cascade systems of the blood (the complement system, the coagulation/contact activation/kallikrein system, and the fibrinolytic system) occurs via activation of zymogen molecules to specific active proteolytic enzymes. Despite the fact that the generated proteases are all present together in the blood, under physiological conditions, the activity of the generated proteases is controlled by endogenous protease inhibitors. Consequently, there is remarkable little crosstalk between the different systems in the fluid phase. This concept review article aims at identifying and describing conditions where the strict system-related control is circumvented. These include clinical settings where massive amounts of proteolytic enzymes are released from tissues, e.g., during pancreatitis or post-traumatic tissue damage, resulting in consumption of the natural substrates of the specific proteases and the available protease inhibitor. Another example of cascade system dysregulation is disseminated intravascular coagulation, with canonical activation of all cascade systems of the blood, also leading to specific substrate and protease inhibitor elimination. The present review explains basic concepts in protease biochemistry of importance to understand clinical conditions with extensive protease activation.
\end{abstract}

This article is a contribution to the special issue on Complement in Health and Disease: Novel Aspects and Insights - Guest Editors: Paul Morgan and David Kavanagh

Bo Nilsson

Bo.Nilsson@igp.uu.se

1 Institute of Clinical and Experimental Trauma-Immunology, University Hospital Ulm, 89081 Ulm, Germany

2 Department of Immunology, Genetics and Pathology (IGP), Rudbeck Laboratory C5:3, Uppsala University, SE-751 85 Uppsala, Sweden

3 Linnæus Center of Biomaterials Chemistry, Linnæus University, SE-391 82 Kalmar, Sweden
Keywords Complement system $\cdot$ Proteases $\cdot$ Protease inhibitors · Trauma

\section{Introduction}

Proteases are expressed ubiquitously in all tissues of the human body. By definition, the word "protein-ase" derives from the Greek word "protelos" $(\pi \rho \omega \tau \varepsilon \lambda o \sigma)$ meaning "first rank"

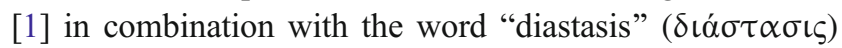
meaning "cleavage" or "separation." Proteases capable of cleaving "first-rank" molecules seem to be excessively released and activated under local inflammatory conditions, resulting in local barrier breakdown, cellular dysfunction, and invasion of inflammatory cells and/or microorganisms. There is longstanding evidence that proteases are involved in many, if not all, acute diseases [2].

\section{General aspects of proteases and enzyme kinetics}

Proteases (or proteinases or peptidases) are enzymes that hydrolyze peptide bonds in substrate proteins and are found in all living organisms, including plants. They are classified on the basis of the catalytic residue in the active site of the particular enzyme. The best-studied groups are serine proteases, cysteine proteases, aspartic proteases, and metalloproteases [3], although additional groups have also been defined. The overall reaction mechanism of a protease-mediated cleavage involves a nucleophilic attack on the target peptide bond in the protease substrate. Generation of a nucleophile can involve a catalytic triad of amino acids (as in serine and cysteine proteases), where a histidine residue removes a proton from a hydroxyl or a thiol in the serine or cysteine, respectively. Aspartic proteases and metalloproteases both activate a water molecule, 
which performs the nucleophilic attack. Metalloproteases have an obligate need for a divalent metal cation in the active site of the enzyme: usually zinc, but in some cases also cobalt.

Here, we present a selection of proteases within each of the main groups that are relevant to the scope of this review article [3]. Within the serine protease group, the chymotrypsin family includes numerous proteases within the complement system, the contact activation (kallikrein)/coagulation system, and the fibrinolytic system. This family also includes enzymes derived from the pancreas such as elastases, endopeptidases, trypsins, and chymotrypsins; leukocyte-originating proteases such as cathepsin G, proteinase 3, and leukocyte elastase; and various tryptases and granzymes. Relevant enzymes within the cysteine protease group are papain, cathepsins $(B, H, K$, $\mathrm{L}, \mathrm{S}$ ), and calpains, and those within the aspartic protease group are pepsin and gastricsin (or pepsinogen C), renin, and cathepsins $\mathrm{D}$ and $\mathrm{E}$. The metalloprotease group includes matrix proteases such as collagenases and gelatinases, which are involved in tissue remodeling, as well as enzymes within the ADAMTS family. In addition, various carboxypeptidases (exopeptidases) belonging to this group are released into the plasma, where some can desarginate and reduce the activity of bradykinin and the anaphylatoxins $\mathrm{C} 3 \mathrm{a}$ and $\mathrm{C} 5 \mathrm{a}$. A summary of proteases relevant to this review article and examples of substrates within the complement system is given in Table 1 .

The specificity of a given enzyme for a substrate varies greatly: promiscuous proteases like trypsin recognize single basic amino acids (Arg or Lys) on the substrate and are consequently able to cleave any protein containing and exposing either of these two amino acids [4]. Like trypsin, thrombin also cleaves its substrates on the carboxyl side of Arg and has multiple substrates, but unlike trypsin, it cleaves each protein at specific positions and with defined kinetics [5]. Elastases usually cleave proteins on the carboxyl-terminal side of amino acids with small, uncharged groups, such as Ala, Gly, or Val [4].

The likelihood for a protease to cleave a given protein target may be expressed in terms of enzyme kinetics as $k_{\text {cat }} /$ $K_{\mathrm{m}}$, or the catalytic efficiency of the enzyme. For an enzyme that follows Michaelis-Menten kinetics, $V_{\max }$ is the maximal velocity at saturating substrate concentration, $K_{\mathrm{m}}$ is the substrate concentration at which the reaction rate is half of that at $V_{\max }$, and $k_{\text {cat }}$ is the turnover number, which relates $V_{\max }$ to the concentration of active sites on the enzyme [6]. $k_{\mathrm{cat}} / K_{\mathrm{m}}$ can be used as a measure of the substrate preference or the catalytic efficiency of the enzyme, or both.

Chymotrypsin is the archetype serine protease, being able to cleave proteins on the carboxyl side of a large hydrophobic or aromatic amino acid. Its substrate preference has been demonstrated using a series of substrates, with increasingly hydrophobic amino acids giving higher and higher $k_{\mathrm{cat}} / K_{\mathrm{m}}$ values, indicating that the most efficient cleavage is obtained for the aromatic amino acid Phe [6].

\section{Properties and specificities of the main intravascular protease inhibitors}

Proteases can be generated in the blood by the activation of the plasma cascade systems (the complement system, the coagulation/contact/kallikrein system, or the fibrinolytic system), which in most cases, lead to the activation of zymogen molecules to yield active proteolytic enzymes. Alternatively, proteases may be released from activated leukocytes and/or damaged tissue or invading pathogens, as in sepsis. Regardless of their origin, proteases present in the blood are controlled by a number of protease inhibitors, which make up $10 \%$ of the total amount of plasma proteins [7]. The inhibitors show great differences in specificity and concentration. $\mathrm{C} 1$ inhibitor (C1-INH) and antithrombin (AT) inhibit the recognition proteases of the classical and lectin pathways of complement and the proteases, which are activated within the contact system. These are factor(F)XIIa, FXIa, kallikrein, and plasmin. AT also inhibits FVIIa, FIXa, FXa, and thrombin within the coagulation system, in addition to trypsin. The serine protease inhibitors (serpins) $\alpha 1$-antichymotrypsin, $\alpha 1$-antitrypsin (which has the alternative designation $\alpha 1$-proteinase inhibitor), $\alpha 2$-antiplasmin, and inter- $\alpha$-trypsin inhibitor mainly inhibit other types of serine proteases (i.e., in addition to those generated within the complement and coagulation systems) such as cathepsin G, chymotrypsin, plasmin, and trypsin in different combinations ( $\alpha 1$-antitrypsin and also collagenases) [8]. Finally, $\alpha 2$-macroglobulin shows the broadest specificity and can inhibit almost any protease of any class, including those of pathogenic origin [9]. A summary of the target specificities and plasma concentrations of these proteases is given in Table 2.

\section{Proteolytic cleavage of key complement components by complement and non-complement proteases}

\section{Complement component C3}

The proteases that cleave the $\alpha$-chain of $\mathrm{C} 3$ under physiological conditions split the protein at distinctive sites within the molecule to yield characteristic fragments (Fig. 1a). These sites are to some extent shared with non-complement proteases, which generate activation products similar to the physiological fragments. It is therefore appropriate to start by describing the physiological fragmentation of $\mathrm{C} 3$ that occurs during $\mathrm{C} 3$ activation. The initial proteolytic cleavage of $\mathrm{C} 3$ is made by the classical/lectin and the alternative pathway $\mathrm{C} 3$ convertases ( $\mathrm{C} 4 \mathrm{bC} 2 \mathrm{a}$ and $\mathrm{C} 3 \mathrm{bBb}$, respectively), which are both restricted to cleaving one Arg-Ser bond at residues $726-727$ in the $\mathrm{C} 3 \alpha$-chain [10] to produce C3a (which is released) and the larger C3b molecule [11] (Fig. 1b). 
Table 1 Selection of proteases within the each of the main groups (serine proteases, cystein proteases, aspartic proteases, and metalloproteases), which have

been reported to cleave

complement components.

Proteases within the complement system, which all belong to the serine protease group, $(\mathrm{C} 1 \mathrm{r}, \mathrm{C} 1 \mathrm{~s}$, MASP1, MASP-2, MASP-3, C2, factor $\mathrm{B}$, factor $\mathrm{D}$, and factor $\mathrm{I}$ ) are not included in the table

\begin{tabular}{|c|c|c|c|}
\hline & Complement substrate & Subtype & Reference \\
\hline \multicolumn{4}{|l|}{ Serine proteases } \\
\hline \multirow[t]{6}{*}{ Trypsins } & $\mathrm{C} 1 \mathrm{q}$ & & {$[45]$} \\
\hline & $\mathrm{C} 1 \mathrm{r}$ & & {$[51]$} \\
\hline & $\mathrm{C} 4$ & & {$[53,56]$} \\
\hline & $\mathrm{C} 3$ & & {$[17,24,26]$} \\
\hline & C2, Factor B & & {$[54,55]$} \\
\hline & $\mathrm{C} 5$ & & {$[36]$} \\
\hline \multirow[t]{2}{*}{ Chymotrypsins } & $\mathrm{C} 1 \mathrm{q}$ & & {$[45]$} \\
\hline & $\mathrm{C} 3$ & & {$[24,25]$} \\
\hline \multirow[t]{4}{*}{ Kallikreins } & $\mathrm{C} 1 \mathrm{~s}$ & Plasma & {$[50]$} \\
\hline & $\mathrm{iC} 3 \mathrm{~b}$ & Plasma & {$[20]$} \\
\hline & $\mathrm{iC} 3 \mathrm{~b}, \mathrm{C} 5$ & KLK3 (PSA) & {$[22]$} \\
\hline & $\mathrm{C} 3$ & KLK14 & {$[23]$} \\
\hline Elastases (leukocyte pancreatic) & $\mathrm{C} 3$ & Leukocyte & {$[27,28]$} \\
\hline Cathepsin A, G & $\mathrm{C} 3$ & $\mathrm{G}$ & {$[154]$} \\
\hline Chymase & $\mathrm{C} 3$ & & {$[155]$} \\
\hline Tryptase & $\mathrm{C} 3, \mathrm{C} 5, \mathrm{C} 4$ & Beta & {$[156]$} \\
\hline Granzyme A, B, C, D, E, F, G, Y & $\mathrm{C} 3, \mathrm{C} 5$ & $\mathrm{~B}$ & {$[72]$} \\
\hline \multicolumn{4}{|l|}{ Coagulation/contact system proteases } \\
\hline FXIIa & $\mathrm{C} 1 \mathrm{r}, \mathrm{C} 1 \mathrm{~s}$ & & {$[52]$} \\
\hline FIXa, FXIa & $\mathrm{C} 5, \mathrm{C} 3$ & & {$[34]$} \\
\hline FXa & $\mathrm{C} 5, \mathrm{C} 3$ & & {$[33,34]$} \\
\hline \multirow[t]{2}{*}{ Thrombin } & $\mathrm{C} 5$ & & {$[32,35]$} \\
\hline & $\mathrm{C} 3, \mathrm{C} 5$ & & {$[33,34]$} \\
\hline \multicolumn{4}{|l|}{ Fibrinolysis system proteases } \\
\hline \multirow[t]{2}{*}{ Plasmin } & $\mathrm{C} 1 \mathrm{~s}$ & & [49] \\
\hline & $\mathrm{C} 3, \mathrm{C} 5$ & & {$[33,34]$} \\
\hline FSAP (factor VII-activating protease) & $\mathrm{C} 3, \mathrm{C} 5$ & & {$[67]$} \\
\hline \multicolumn{4}{|l|}{ Cysteine proteases } \\
\hline Papain & $\mathrm{C} 1 \mathrm{q}$ & & {$[44]$} \\
\hline \multicolumn{4}{|l|}{ Aspartic proteases } \\
\hline Pepsin & $\mathrm{Clq}$ & & {$[44,46]$} \\
\hline Cathepsin D, E & $\mathrm{C} 5$ & $\mathrm{D}$ & {$[82]$} \\
\hline \multicolumn{4}{|l|}{ Metallo- proteases } \\
\hline Collagenases (neutrophil, interstitial) & $\mathrm{C} 1 \mathrm{q}$ & & {$[45,47,48]$} \\
\hline Carboxypeptidase A, B, H, M, N & $\mathrm{C} 3 \mathrm{a}, \mathrm{C} 5 \mathrm{a}$ & $\mathrm{B}, \mathrm{N}$ & {$[41,43]$} \\
\hline
\end{tabular}

The next three physiological cleavages are mediated by the serine protease factor I. Factor I exposes its catalytic site directly upon contact with $\mathrm{C} 3 \mathrm{~b}$ [12], but in order for cleavage to occur, there is an absolute requirement for one of several cofactors: factor $\mathrm{H}$ in the plasma, or membrane-bound MCP or CR1 [13, 14]. Its cleavage sites are located close together in the CUB domain of $\mathrm{C} 3 \mathrm{~b}$. The first is located at positions 1281-1282, and the second at positions 1289-1290; both are Arg-Ser sequences whose cleavages produce $\mathrm{C} 3 \mathrm{f}$ and the main $\mathrm{iC} 3 \mathrm{~b}$ fragment $[15,16]$ (Fig. 1b). A third major cleavage occurs at positions 932-933 (Arg-Glu) [17], cleaving the $\mathrm{C} 3 \mathrm{~d}, \mathrm{~g}$ fragment from $\mathrm{iC} 3 \mathrm{~b}$ to produce the larger $\mathrm{C} 3 \mathrm{c}$ fragment
(Fig. 1b). An additional cleavage at 937-938 (Lys-Glu) has also been reported [12].

$\mathrm{C} 3 \mathrm{a}$ binds to $\mathrm{C} 3 \mathrm{aR}$ and $\mathrm{C} 3 \mathrm{~b}$ interacts with complement receptor 1 (CR1, CD35), $\mathrm{iC} 3 \mathrm{~b}$ binds to $\mathrm{CR} 3$, and CR4 (CD11b/CD18; CD11c/CD18) binds to CR2 (CD21), and $\mathrm{C} 3 \mathrm{~d}, \mathrm{~g}$ is another ligand for CR2. The differential binding of the $\mathrm{C} 3$ fragments represent regulation of $\mathrm{C} 3$ function. From being a fragment for cell lysis, cell adherence and cell activation (CR1, CR3, and CR4) during phagocytosis, cytotoxicity, etc., C3 becomes transformed to a ligand for immunoregulation (CR2), thereby linking innate and adaptive immunity, reviewed in [18]. 
Table 2 Main protease inhibitors in human plasma. Normal concentration and targets

\begin{tabular}{|c|c|c|c|c|}
\hline \multirow[t]{2}{*}{ Inhibitor } & \multirow{2}{*}{$\begin{array}{l}\mathrm{Mw} \\
\mathrm{kDa}\end{array}$} & \multicolumn{2}{|c|}{ Plasma concentration } & \multirow[t]{2}{*}{ Targets (preferred target first) } \\
\hline & & $\mathrm{mg} / \mathrm{L}$ & $\mu \mathrm{M}$ & \\
\hline C1-inhibitor (C1-INH) & 100 & 240 & 2.4 & $\begin{array}{l}\text { C1r, C1s, MASP-1/2, } \\
\text { FXIIa, FXIa, kallikrein, } \\
\text { plasmin }\end{array}$ \\
\hline Antithrombin (AT) & 58 & 240 & 4.1 & $\begin{array}{l}\text { Thrombin, FXa, C1s, MASP-1/2, FXIIa, FXIa, kallikrein, } \\
\text { VIIa, FIXa, plasmin, trypsin }\end{array}$ \\
\hline$\alpha 1$-Antichymotrypsin & 63 & 490 & 8 & Cathepsin G, chymase, chymotrypsin \\
\hline$\alpha 1$-Antitrypsin $(=\alpha 1$ proteinase inhibitor $)$ & 53 & 2900 & 55 & Elastase, trypsin, chymotrypsin, collagenases, cathepsin G, plasmin \\
\hline$\alpha 2$-Antiplasmin & 68 & 70 & 1 & Plasmin, trypsin, (chymotrypsin, kallikrein, FXa, FXIa) \\
\hline Inter- $\alpha$-trypsin inhibitor & 180 & 500 & 2.8 & Trypsin, chymotrypsin, plasmin (slow) \\
\hline 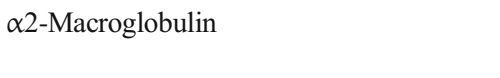 & 725 & 2600 & 3.6 & $\begin{array}{l}\text { Most proteases of all classes including cathepsins, granulocyte and } \\
\text { pancreas proteases, collagenases, kallikrein, FXa, thrombin, and plasmin }\end{array}$ \\
\hline
\end{tabular}

Additional physiological fragments have also been described. C3e was first identified as a leukocytosis-inducing peptide, although the origin of this fragment was not identified at the time [19]. A few decades after the identification of the $\mathrm{C} 3 \mathrm{e}$ fragment, another possibly related fragment was identified. It was a $\mathrm{C} 3 \mathrm{~d}, \mathrm{~g}$-like fragment that could be generated by cleavage of $\mathrm{iC} 3 \mathrm{~b}$ using the contact system protease kallikrein (Fig. 1b). This C3d-k fragment contained a few amino acid residues more than $\mathrm{C} 3 \mathrm{~d}, \mathrm{~g}$ and exhibited leukocytosis-like properties, possibly linking $\mathrm{C} 3 \mathrm{e}$ and C3d-k [20, 21].

Intriguingly, another member of the kallikrein (KLK) serine protease family, KLK3 or prostate-specific antigen (PSA), has been shown to digest purified iC3b (but not $\mathrm{C} 3$ or $\mathrm{C} 3 \mathrm{~b}$ ), in addition to $\mathrm{C} 5$ (but not $\mathrm{C} 4$ ). The cleavage of iC 3 b occurs at a chymotrypsin-like cleavage site (Tyr1348) without the aid of factor $\mathrm{H}$ or $\mathrm{CR} 1$ and gives rise to a novel fragment originating from the $45-\mathrm{kDa}$ portion (Fig. 1b). The same pattern of C3 cleavage has also been seen in prostatic fluid and seminal plasma, where $\mathrm{C} 3$, but not $\mathrm{C} 5$, is present [22]. In addition, KLK14 has been reported to cleave $\mathrm{C} 3$, thereby generating functionally active C3a without downstream generation of C5a [23].

Trypsin, chymotrypsin, and elastase [4] have broad specificities and cleave the whole native $\mathrm{C} 3$ molecule into small proteolytic fragments in a dose-dependent manner [24, 25]. Basically, the cleavage regions are the same as for the physiological cleavages, potentially generating proteolytic fragments with biological activity. For instance, low concentrations of trypsin generate $\mathrm{C} 3 \mathrm{a}$ and $\mathrm{C} 3 \mathrm{~b}$ and facilitate the cleavage of $\mathrm{C} 3 \mathrm{~d}, \mathrm{~g}$ to $\mathrm{C} 3 \mathrm{~d}$ and $\mathrm{C} 3 \mathrm{~g}[17,24,26]$, and elastase has been reported to promote similar digestion [27, 28]. A schematic overview of proteolytic digestion of $\mathrm{C} 3$ and the resulting fragments is presented in Fig. $1 \mathrm{~b}$.

\section{Complement component C5}

The physiological cleavage of C5, which is homologous to $\mathrm{C} 3$, is much less well understood and probably more complex. As with $\mathrm{C} 3, \mathrm{C} 5$ is cleaved into $\mathrm{C} 5 \mathrm{a}$ and $\mathrm{C} 5 \mathrm{~b}$ by $\mathrm{C} 5$ convertases, generated by the classical/lectin and alternative pathways [29-31]. In addition, a number of studies have shown that non-complement proteases, particularly proteases from the coagulation cascade (e.g., thrombin, FXa, and plasmin), are able to cleave native C5 into C5a and C5b [32-34] (also discussed below). These findings are contradicted by other studies in which, for example, thrombin has been reported to generate a form of $\mathrm{C} 5$, which is cleaved at the corresponding third "factor I cleavage site" and not at the convertase site, to generate a form designated $\mathrm{C} 5 \mathrm{~T}$, which is still able to support the formation of the terminal pathway complex, C5b-9 [35]. This form of $\mathrm{C}_{\mathrm{T}}$ is also generated when native C5 is exposed to trypsin at low concentrations [36] (Prof. Ulf Nilsson, personal communication). Plasmin and FXa are the proteases that most likely cleave C5 at the convertase site at reasonable concentrations to generate $\mathrm{C} 5 \mathrm{a}$ and $\mathrm{C} 5 \mathrm{~b}$. The discrepancies between studies may be explained by findings in the $\mathrm{C} 5$ crystal structure at a resolution of $3.1 \AA$ [37]. Unlike C3, the cleavage site for the convertases in C5 is hidden in the native molecule, necessitating a conformational change in the molecule before the site becomes accessible. The mechanism inducing this conformational change is not known but is probably the key to understanding the function of the abovementioned proteases and C5 convertases.

\section{Cleavage of $\mathrm{C} 3$ and $\mathrm{C} 5$ by coagulation proteases}

In addition to these proteases, other activated coagulation factors have been shown to generate $\mathrm{C} 3 \mathrm{a}$ and $\mathrm{C} 3 \mathrm{~b}$, thereby 
Fig. 1 Cleavage of $\mathrm{C} 3$ by complement and non-

complement proteases. a

Summary of cleavages; $\mathbf{b}$ localization of reported cleavage sites in three regions in the $\alpha$ chain of $\mathrm{C} 3$ (top) leading to generation of $\mathrm{C} 3$-fragments. $\mathrm{C} 3$ is activated to $\mathrm{C} 3 \mathrm{a}$ and $\mathrm{C} 3 \mathrm{~b}$, by the $\mathrm{C} 3$ convertases of the classical/ lectin pathways and/or the alternative pathway (1). C3b is subsequently cleaved by factor I together with co-factors into $\mathrm{iC} 3 \mathrm{~b}$ (2), C3c, C3d,g, and smaller fragments (3). Similar cleavages can also be accomplished by proteases like trypsin,

chymotrypsin, and elastase. In addition, $\mathrm{iC} 3 \mathrm{~b}$ has been reported to be cleaved by PSA (KLK3) to $\mathrm{i}-\mathrm{pC} 3 \mathrm{~b}_{2}(2)$ and by kallikrein (KLK1B) to C3d-k (3). C3a is cleaved at the $\mathrm{C}$-terminal end by carboxypeptidases generating $C 3 \mathrm{a}_{\text {desArg }}$ (1). $A P$ alternative pathway, $C P$ classical pathway, $L P$ lectin pathway, $P S A$ prostatespecific antigen, $F H$ factor $\mathrm{H}$, $M C P$ membrane cofactor protein, $C R 1$ complement receptor-1, $P S A$ prostate-specific antigen, $K L K$ kallikrein, $C P N / B 2$

carboxypeptidase N/B2, TAFI thrombin-activatable fibrinolysis inhibitor
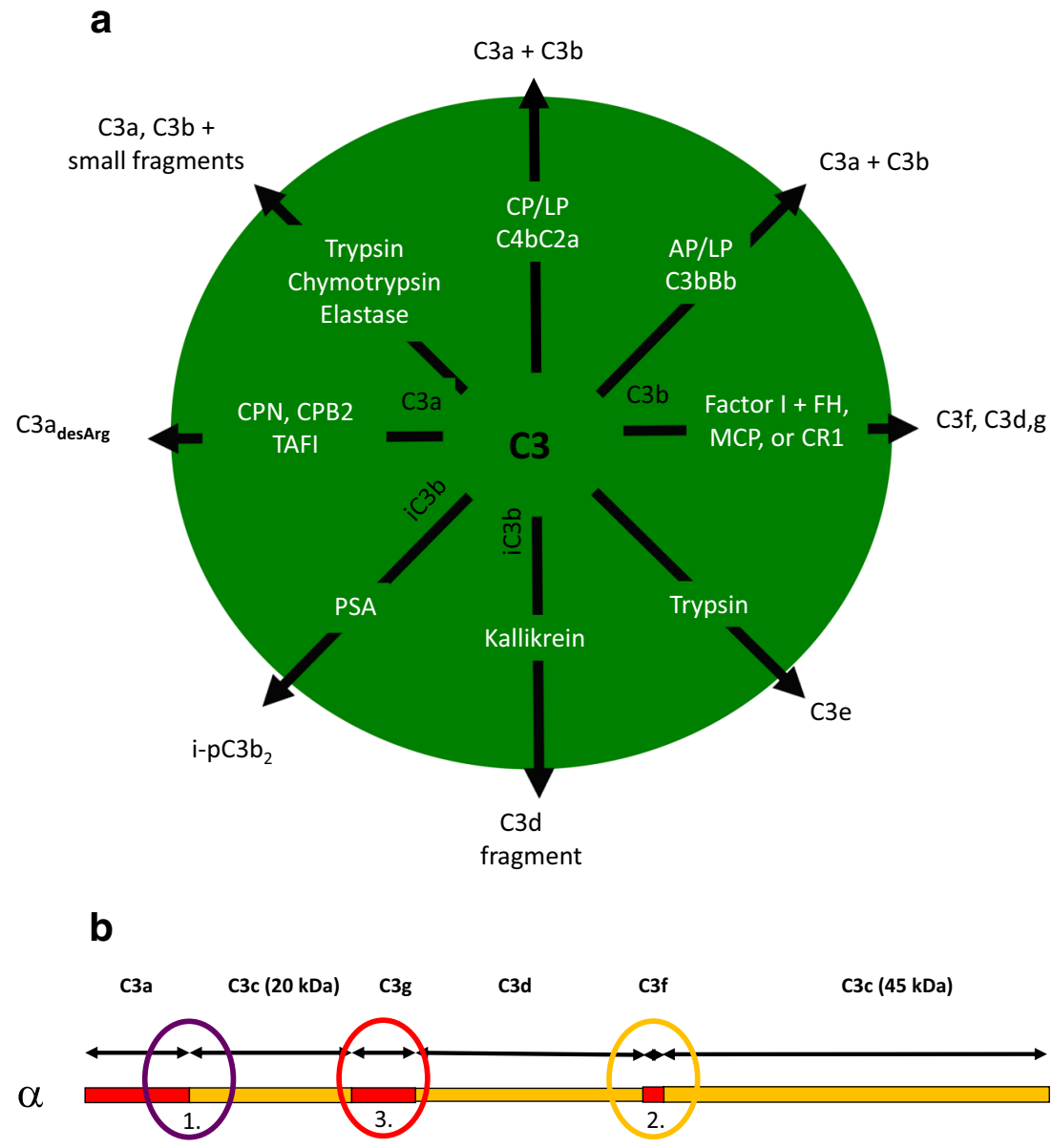

producing anaphylactic activity. Several components have been reported to have this activity in purified in vitro systems: FXa, thrombin, FIXa, and FXIa in decreasing order of strength [33], in addition to plasmin [34]. Also, complement activation is triggered when FXa in relatively low concentration $(>0.2 \mu \mathrm{g} / \mathrm{mL})$ is added to serum (Table 3 ). The activation results in $\mathrm{C} 3 \mathrm{a}$ and $\mathrm{C} 5 \mathrm{a}$ generation, decreased hemolytic activity, and increased anaphylactic activity. The complement- activating activity is blocked by anticoagulants, e.g., fondaparinux [33]. These studies show that coagulation factors can activate complement in a complex serum milieu. However, it is likely that the activity would be lower in plasma containing intact native coagulation factors, which are the preferred substrates. In many experiments with purified components, the concentrations of proteases added have been close to the theoretical limit, i.e., if the total amount of each 
Table 3 Normal plasma concentration of zymogens of coagulation proteases reported to cleave complement components (top section). Normal plasma concentration of complement components reported to be cleaved by coagulation proteases (lower section)

\begin{tabular}{llll}
\hline Coagulation zymogen & Mw & \multicolumn{2}{c}{ Plasma concentration } \\
& $\mathrm{kDa}$ & $\mathrm{mg} / \mathrm{L}$ & $\mu \mathrm{M}$ \\
FXII & 100 & 30 & 0.3 \\
FXI & 160 & 5 & 0.03 \\
FX & 55 & 10 & 0.2 \\
FIX & 55 & 5 & 0.09 \\
Prothrombin & 72 & 140 & 1.9 \\
Plasminogen & 90 & 130 & 1.4 \\
Complement component & $\mathrm{Mw}$ & Plasma concentration \\
& $\mathrm{kDa}$ & $\mathrm{mg} / \mathrm{L}$ & $\mu \mathrm{M}$ \\
C1q & 400 & 250 & 0.6 \\
C1r & 80 & 50 & 0.6 \\
C1s & 85 & 50 & 0.6 \\
C4 & 200 & 400 & 2 \\
C3 & 185 & 1500 & 8 \\
C2 & 108 & 20 & 0.2 \\
Factor B & 93 & 200 & 2.1 \\
C5 & 180 & 80 & 0.4 \\
\hline
\end{tabular}

zymogen had been converted to an active enzyme. In addition, in these studies, the proteases have been tested one at a time, so the question of possible synergistic effects has not been addressed [33, 34]. There are, however, several situations in the clinical setting in which these conditions are approached, for instance in disseminated intravascular coagulopathy (DIC) or sepsis, when all these systems are exhausted, and the intravascular protease inhibitors have been consumed (e.g., [38, 39]). Furthermore, under such dysregulated circumstances, a small amount of $\mathrm{C} 3$ activation (generated by coagulation proteases, alone or in combination) may be sufficient to initiate a full-blown inflammation as a result of amplification by the alternative pathway of complement.

A number of human pathogens, e.g., Borrelia, Streptoccocus, and Leptospira interrogans acquire plasminogen on their surfaces and use the proteolytically active plasmin to cleave and inactivate $\mathrm{C} 3$ and $\mathrm{C} 5$ in order to disarm the host immune defense (see, e.g., [40] and references therein).

\section{Desargination of C3a and C5a}

Both $\mathrm{C} 3 \mathrm{a}$ and $\mathrm{C} 5 \mathrm{a}$ are cleaved at the $\mathrm{C}$-terminal end by carboxypeptidases, generating $\mathrm{C} 3 \mathrm{a}_{\text {desArg }}$ and $\mathrm{C} 5 \mathrm{a}_{\text {desArg }}$ [41]. These fragments have a lower affinity for the C3aR and $\mathrm{C} 5 \mathrm{aR} 1$ receptors and are therefore considered inactivated forms of the anaphylatoxins, although they are not totally without effect [42]. The active carboxypeptidases are carboxypeptidase $\mathrm{N}$ and carboxypeptidase $\mathrm{B} 2$, the latter being more active and derived from procarboxypeptidase $\mathrm{R}$ (thrombin-activatable fibrinolysis inactivator (TAFI) of the coagulation/fibrinolytic cascade), further illustrating the linkage between the coagulation and complement systems [43].

\section{Cleavage of classical pathway components by non-complement proteases}

Proteolytic digestion is not a feature of $\mathrm{Clq}$ activation, but there are several reports suggesting that $\mathrm{C} 1 \mathrm{q}$ may be cleaved by proteases that do not belong to the complement system. Human C1q has shown to be sensitive to digestion by trypsin, chymotrypsin, pepsin, and collagenase [44-47]. In contrast to trypsin and chymotrypsin, collagenase treatment of $\mathrm{Clq}$ leads to the production of well-defined fragments, which show only moderately decreased binding to immune complexes when compared to intact C1q [45, 48]. Not surprisingly, C3 and C5 (in addition to the rest of the terminal components) have been shown to be refractory to collagenase [47].

Rabbit C1s has been shown to be activated by plasmin [49]. In addition, it has been demonstrated that kallikrein digestion of activated $\mathrm{C} 1 \mathrm{~s}$ markedly decreases its hydrolytic activity toward $\mathrm{C} 4$ without affecting its activity toward $\mathrm{C} 2$ [50].

C1r has been reported to be cleaved by trypsin, but this cleavage occurs at a site that is distinct from the autocleavage site and does not activate $\mathrm{C} 1 \mathrm{r}$ [51]. In addition, $\mathrm{C} 1 \mathrm{r}$ and $\mathrm{C} 1 \mathrm{~s}$ are both activated by FXIIa, and since activation of $\mathrm{C} 1 \mathrm{~s}$ is much less efficient, it was concluded that it is primarily activated by $\mathrm{C} 1 \mathrm{r}$ and only to a lesser degree by FXIIa [52].

$\mathrm{C} 4$ and $\mathrm{C} 2$ (as well as factor B) are cleaved by trypsin [53-55]. Recently, it was demonstrated by co-crystallization of C4-MASP2 and C4-trypsin, in conjunction with activation measurements, that trypsin indeed is able to activate $\mathrm{C} 4$ [56].

\section{Clinical settings enabling massive release of proteolytic enzymes}

In the clinical setting of acute pancreatitis or during the development of abscesses, inflamed/infected tissues may be decomposed as a result of uncontrolled activation of proteases. Moreover, in systemic inflammatory conditions, proteases seem to act as major drivers of pathophysiological inflammation and organ dysfunction. For example, during sepsis, defined as a systemic inflammatory response syndrome (SIRS) in the presence of pathogens, enhanced levels of trypsin [57], elastase [58], and metalloproteinase 9 [59], as well as many other enzymes, are detected and are held responsible for the generation of the inflammatory response. It is noteworthy that the released proteases can originate from the host and/or from invading microorganisms that contain enzymes with similar or diverse functions. For example, in the case of 
Lyell's syndrome, manifested as an acute life-threatening epidermolysis, two different forms exist: one is a sterile, drug-induced toxic epidermal necrolysis (TEN), in which host proteases are responsible for detaching the epidermis from the dermis after drug administration, making the entire body susceptible to subsequent infectious invasion and complications. The other form, known as staphylococcal scalded skin syndrome (SSSS), is induced by the serine protease exfoliatin, which is released by invading Staphylococcus aureus and finally results in a highly specific breakdown of desmosomes $[60,61]$.

In other diseases associated with complex systemic reactions, such as hemorrhagic shock (HS), acute kidney injury (AKI), and adult respiratory distress syndrome (ARDS), proteases function as important inflammatory trailblazers. Excessive systemic activation of proteases may even result in a proposed "autodigestion" phenomenon [62,63], which may be clinically crucial for the development of multiple-organ dysfunction syndrome (MODS) and often fatal multiple organ failure (MOF). In the case of multiple trauma (polytrauma), protease release and activation have been described [64-67] and may also be responsible for systemic activation and depletion of the coagulation system, manifested as acute trauma-induced coagulopathy. On the other hand, the intensive crosstalk between the complement and coagulation cascades, accompanied by platelet activation and various proteases and their inhibitors, is critically involved in any thrombus formation [68]. Taken together, these findings indicate that in many acute diseases, proteases can act as local and systemic groundbreakers for tissue invasion by pathogen-associated molecules (PAMPs) and immune cells, generating all the classical signs of inflammation ("tumor, rubor, dolor, calor, function laesa"), which can easily affect the whole body. Therefore, specific therapeutic targeting of proteases beyond the complement and coagulation cascades represents a promising subject for research and clinical investigations in the future [69]. An overview of different clinical settings, which enable massive release of proteolytic enzymes is found in Fig. 2.

\section{Protease crosstalk in various clinical conditions-therapeutic implications}

\section{Acute life-threatening epidermolysis}

Several decades ago, both the complement and coagulation systems were proposed to be important actors in the development of TEN (Lyell's syndrome), which is caused by proteolytic shedding of the epidermis in response to certain drugs or occasionally to microorganisms [70]. Stevens-Johnsonsyndrome (SJS) and TEN differ only in their degree of epidermal detachment, with an affected body surface area of $<10 \%$ in case of SJS and $>30 \%$ for TEN (with SJS/TEN overlap in between). Pathophysiologically, this disease represents a

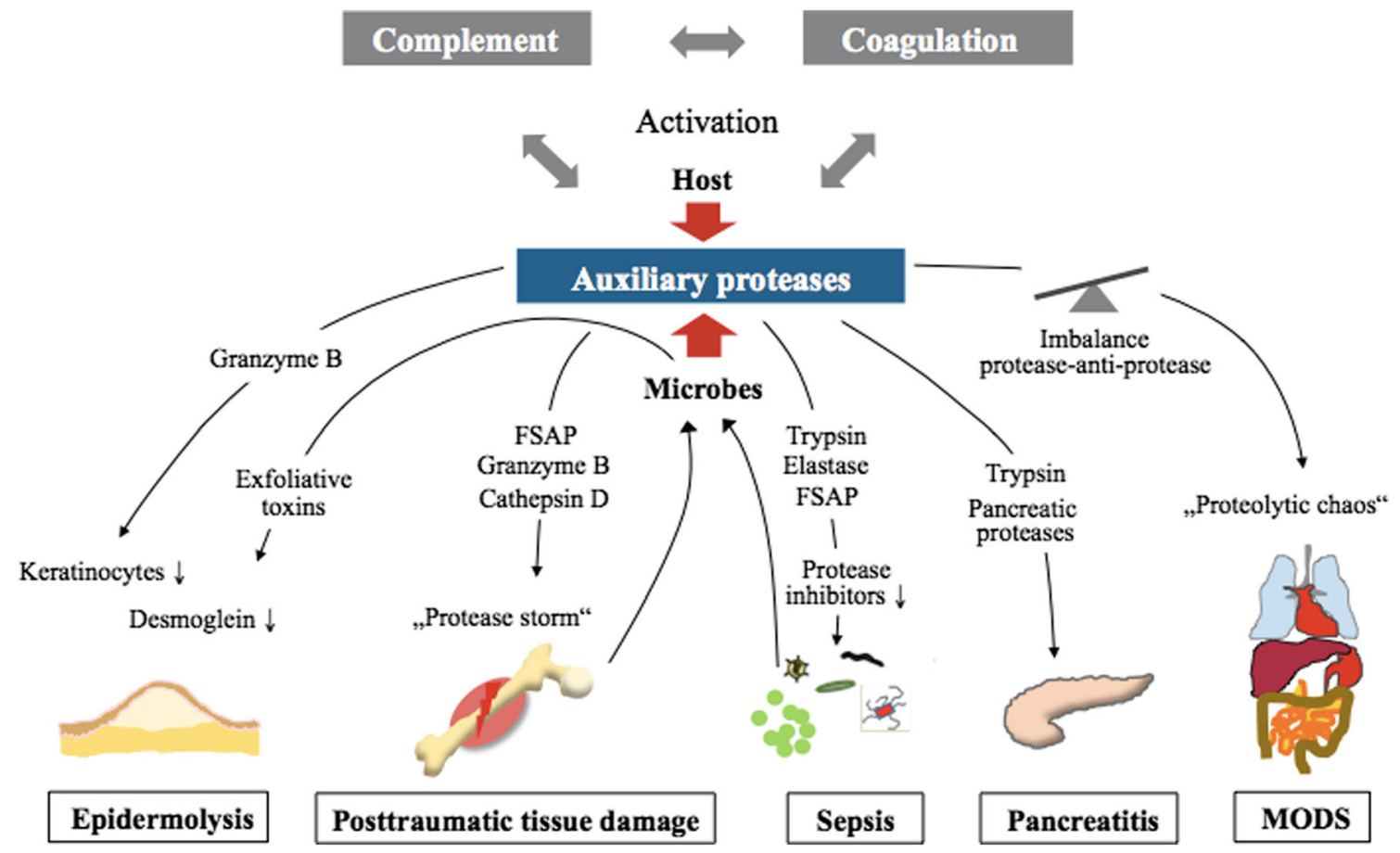

Fig. 2 Involvement of protease activity in various diseases. Activation of the interconnected host complement and coagulation cascade can augment cleavage of auxiliary proteases and vice versa, inducing the release of downstream effectors responsible for disease induction or

generalization. Proteases released from damaged tissue after trauma or invading pathogens during sepsis can further increase the inflammatory response. FSAP factor VII-activating protease, MODS multiple-organ dysfunction syndrome 
severe hypersensitivity reaction, with activation of cytotoxic $\mathrm{T}$ lymphocytes and natural killer cells; these cells, in turn, mediate immune reactions directed at keratinocytes. Furthermore, the immune reaction is associated with the release of cytokines, perforin, granzyme B, and several proteases, finally resulting in keratinocyte death and disintegration of the epidermis [71]. Although it is not yet implicated in this life-threatening skin disease, the serine protease granzyme B has been shown to directly activate complement in a noncanonical manner, generating the anaphylatoxins $\mathrm{C} 3 \mathrm{a}$ and C5a [72], which can induce all the cardinal signs of inflammation. Given the rarity of these diseases, there are no randomized clinical trials for SJS or TEN. However, in some clinical case reports, trypsin inhibition by ulinastatin has been beneficial [73].

The related disease SSSS, caused by PAMPs, toxins, and proteases from Staphylococcus aureus, seems to critically involve complement activation and dysregulation [74]. Staphylococcus and its toxins can not only activate complement and coagulation but can also evade complement surveillance [75]. For example, there are staphylococcal complement inhibitors (SCINs) that effectively stabilize $\mathrm{C} 3$ convertases in a non-functional state, allowing them to escape complement attack [75]. Exfoliative toxins from S. aureus are serine proteases that cleave desmoglein 1 , the most important component for the structural integrity of the epidermis [76]. Whether these toxins can also cleave, activate, or deactivate complement or coagulation factors remains to be clarified.

\section{Trauma and hemorrhagic shock}

After severe tissue injury, a rapid activation of both the complement and coagulation cascades has been reported [77, 78], with the potential development of a harmful trauma-induced coagulopathy and complementopathy [77]. Although the importance of crosstalk between the two cascades has been postulated, only a few clinical studies have assessed its direct impact and importance for traumatized and critically ill patients. One study has analyzed septic patients as compared to multiple-injury patients and has found enhanced plasma levels of C3a, C5a, and leukocytes but reduced plasma fibrinogen and platelet counts [79]. Remarkably, in addition to increased MOF scores and lactate concentrations, reduced C1-INH activity was the only reliable predictor of poor outcome [79]. This result emphasizes the importance of cross-regulatory drivers, since C1-INH blocks not only the activation of complement and coagulation but also the activation of the contact system. It is tempting to speculate that after polytrauma, extensive tissue damage, ischemic stress, acidosis, hypothermia, and reactive oxygen radicals may locally generate complement and coagulation activation products in an attempt to control bleeding and inflammation. Furthermore, systemic activation of protease systems beyond the complement and coagulation cascades may result in a "proteolytic chaos," which in turn will further (non)specifically cleave and activate complement and coagulation factors. It is still unknown whether these cleavage products appear as native proteins with established structure-function relationships or exhibit novel functions. Extensively enhanced activity factor VII-activating protease (FSAP), representing an ancient coagulation factor, was found to be associated with increased plasma levels of the anaphylatoxins C3a and C5a early after polytrauma [67]. In vitro exposure of FSAP to key complement components revealed its ability to cleave $\mathrm{C} 5$ into a C5a fragment, which, however, lacked four amino acids at the $\mathrm{N}$ terminus, interestingly without altering the molecule's functional profile. FSAP-induced C3 cleavage resulted in two differently sized cleavage products, whose exact functions in vitro and in the clinical setting are still unknown [67].

After clinical trauma to the thorax, enhanced levels of C5a have been found in bronchoalveolar lavage (BAL) fluids, depending on the volume of the contused lung tissue and subsequent development of pneumonia [80]. In the same study, the authors showed enhanced C5a levels in BAL fluids after trauma in a re-translational approach employing a rodent thorax trauma model. Interestingly, blockade of thrombin, a potent serine protease, by hirudin not only reduced thrombin levels but also significantly reduced $\mathrm{C} 5 \mathrm{a}$ concentrations, pointing to thrombin-induced complement activation as a major contributor to acute lung injury after blunt chest trauma [80]. Similarly, plasma concentrations of the serine protease granzyme B were shown by our group to be increased in the early stages after multiple injuries in humans and again to be able to generate anaphylatoxins in vitro [72]. Moreover, granzyme B has also been shown to cleave von Willebrand factor (vWF) and the matrix form of fibrinogen at several sites, resulting in an overall anticoagulatory activity [81]. Other protease species seem to be generated rapidly after severe tissue trauma. For example, the aspartyl-protease cathepsin D is significantly increased in plasma from patients early after polytrauma and may generate a C5a-like protein, although cleavage of the classical serine moiety is rather unlikely [82].

The exact origins and mechanisms of protease activity after severe tissue trauma are not well defined. Nevertheless, it is somehow surprising that some protease inhibitors that not only effectively address protease-induced host damage but also control the coagulation, and complement systems have not been tested in the experimental and clinical trauma setting. A previous experimental report in trauma-hemorrhagic shock described improved survival rates when an elastase inhibitor was applied, resulting in reductions in a cardio-depressive factor [83]. Similarly, in a traumatic spinal cord injury model, the elastase inhibitor showed promising results in blocking the sensor system for nitric oxide, promoting functional recovery, 
and reducing the inflammatory response. However, nothing was reported about complement or clotting effects in particular [84], and no valid translational data are available.

In case of the trypsin inhibitor ulinastatin, a small study in trauma-hemorrhagic shock patients has been performed and revealed only modest early effects, such as reduction in serum neutrophil-derived elastase within $45 \mathrm{~h}$, but no effects on clinically relevant parameters or scores [85]. A recent clinical study (NCT01275976) in the complex setting of polytrauma, in which $200 \mathrm{U} / \mathrm{kg} \mathrm{C} 1-\mathrm{INH}$ was infused over $30 \mathrm{~min}$ (just before the start of the femoral or pelvic fixation operation), has been terminated, but the final results have not yet been published [86]. The most well-developed and well-evaluated protease inhibitors in the clinic, such as aprotinin (Trasylol®), inhibit serine proteases. A meta-analysis examining orthopedic surgery that is associated with significant tissue trauma has indicated that there are benefits from serine protease blockade: reduced blood loss and need for transfusions, and no enhanced risk for thromboembolic events [87]. Other reports in a pig model of hemorrhagic shock have indicated that local application of the synthetic serine protease inhibitor nafamostat produces some improvement in clinical outcome parameters [88]. However, there are no reliable data available for serine protease inhibitory strategies for complex polytrauma conditions.

Taken together, the data indicate that although there is evidence of a "protease storm" after severe tissue trauma, inhibition of specific proteases in the trauma-hemorrhage situation seems to be of limited help in the complex clinical setting. Such an approach may even further disturb the acute trauma-induced coagulopathy, and thus, further experimental pathophysiological investigation is certainly warranted.

\section{Sepsis}

In human sepsis, defined as an infectious whole-body inflammation, it has been established that during the induction and progression of the systemic response, there is a massive activation of the complement system $[89,90]$ and the coagulation cascade [91]. This activation may result in immune dysfunction, complementopathy, coagulopathy, and (multiple) organ dysfunction. The importance of the complement-coagulation interplay in the pathophysiological development of sepsis has been demonstrated in non-human primates [92]. In particular, systemic $\mathrm{C} 3$ depletion has been found to be associated with the development of coagulopathy (elevated D-dimers), infectious complications, and poor prognosis in septic patients [93]. In progressive sepsis, an uncontrolled systemic protease activity has been reported, with enhanced serum concentrations of trypsin [57] and elastase [58, 94] and serine protease activity, e.g., of FSAP [95]. This "global protease activation" may be mainly responsible for the impaired inhibition of endogenous proteases, e.g., a drop in AT plasma concentrations
[96]. Accordingly, AT substitution during severe sepsis in humans has been shown to reduce IL- 6 concentrations in serum as surrogate parameter and to also reduce overall mortality $[97,98]$. Interestingly, in humans, antithrombin, acting as a specific protease inhibitor, has been found to display antimicrobial activity [99] that might prove supportive in sepsis therapy. Furthermore, in septic trauma patients, enhanced elastase levels seem to contribute significantly to the tissue factor (TF) - TF pathway inhibitor (TFPI) imbalance, which in turn aggravates ARDS development and sustained systemic inflammation [94]. Of note, when administered to patients with abdominal sepsis and ARDS, the selective neutrophil elastase inhibitor sivelestat results in early improvement in oxygenation and ventilator weaning, as well as improved multiple organ function [100]. In this context, experimental data have shown that specific elastase inhibition significantly attenuates not only endotoxin-induced septic acute lung injury but also reduces C5a and IL-6 concentrations in the alveolar space [101].

In rodents, sepsis-induced pro-coagulatory activity and synchronic signs of DIC, as indicated by prolonged activated partial thromboplastin time (APTT), reduced platelet count, thrombin-antithrombin (TAT) complexes, D-dimers, and tissue-plasminogen activator (t-PA), are mostly reversed by C5a blockade, resulting in an improved survival rate [102]. This study illustrates the clinical potency of the crosstalking serine protease systems. It is therefore not too surprising that multiple serine protease inhibitory strategies have been clinically applied in the past, albeit not predominantly in sepsis. In a small retrospective single-center study that investigated patients with sepsis-induced DIC, gabexate mesilate as serine protease inhibitor versus recombinant thrombomodulin, thrombomodulin was found to be more effective in improving platelet counts, $\mathrm{C}$-reactive protein (CRP) concentrations, and MOF [103]. At the same time, ulinastatin as a multi-functional serine protease inhibitor has been proposed as "an exciting candidate" for sepsis therapy [104]. Recent meta-analyses have stated that ulinastatin alone or in combination with thymosin $\alpha 1$ indeed results in an improved overall survival, reduced generation of inflammatory mediators, and a shortened need for mechanical ventilation [105-107].

An illuminating study in humans admitted to the intensive care unit with SIRS has revealed that approximately $25 \%$ of all proteins mapped to either the coagulation or complement system are differently expressed in patients who develop sepsis versus non-septic SIRS [108]. Strikingly, differences in some complement and coagulation proteins in these SIRS patients were capable of predicting a septic course even $60 \mathrm{~h}$ before sepsis became clinically evident. Moreover, $36 \mathrm{~h}$ before sepsis onset, the plasma levels of various endogenous protease inhibitors, such as $\alpha 1$-antitrypsin and AT, were decreased, suggesting that specific protease inhibitor application might serve as a reasonable therapeutic strategy for 
ameliorating or inhibiting sepsis development [108]. However, more clinical studies are needed to precisely define the most appropriate indications, timing, and dosage for protease inhibitors in coagulatory and inflammatory disorders during sepsis.

\section{Multiple-organ dysfunction syndrome}

Multiple-organ dysfunction syndrome (MODS) may be considered a final pathophysiological escalation route in various diseases, such as polytrauma, severe infection, sepsis, and hemato-oncological diseases. MODS, defined by a significant incremental functional derangement of at least two or more organs, is still associated with a high mortality rate. Interestingly, during MODS, the major functional defects are not necessarily reflected by major morphological defects [109], even though multiple functionally crosstalking organ systems such as the liver-kidney, lung-kidney, and brain-gut axes are involved in the complex organ response. In the case of severe ARDS, a clinical proteomic analysis has revealed not only protease-antiprotease imbalances with significantly enhanced truncated forms of $\alpha 1$-antitrypsin but also an associated complement activation with increased $\mathrm{C} 4$ levels that is indicative of a tightly interacting pulmonary proteaseinflammation response [110]. In this context, it is not too surprising that also in the case of ARDS, a recent metaanalysis of clinical studies has pointed to beneficial effects from blocking trypsin using ulinastatin, although data on complement and coagulation were missing [111]. In the last two decades, crosstalking complement and coagulation cascades have also been described as being involved in triggering and promoting the development of MODS [112-115]. Consequently, blockade of $\mathrm{C} 5 \mathrm{a}$ in cecal ligation and puncture-induced sepsis and subsequent MODS has proved protective not only with regard to the coagulatory response [102] but also for organ performance, i.e., improved oxygenation of the lungs, reduction in lactate generation, and amelioration of acute liver and kidney injury [113]. In a non-human primate model of E. coli-induced MODS, blockade of complement factor $\mathrm{C} 3$ by the inhibitor compstatin has not only inhibited central complement activation but also reduced signs of coagulopathy (reduced TF, plasminogen activator inhibitor1 (PAI-1), fibrinogen, fibrin-degradation products, APTT) while maintaining the anticoagulatory properties of the endothelium [116]. Furthermore, compstatin has improved the hemodynamics and, concurrently, liver and kidney function, with evidence of fewer microvascular thrombi and improved vascular barrier function [116]. In the clinical setting, an integrated clinico-transcriptomic approach has recently correlated early thrombocytopenia with MODS development and C5 expression levels with nosocomial infections [117].

Regarding the therapeutic inhibition of non-canonical crosstalking protease systems, the trypsin inhibitor ulinastatin has been found to exert some protective effects on the immune response and hemostasis [118]. Similarly, in vitro thrombelastometric analyses have indicated some anticoagulatory effects [119]. Translational studies in abdominal surgery have shown evidence not only of antiinflammatory effects (via inhibition of neutrophil elastase activity) but also of anticoagulatory and antifibrinolytic effects (via reduction in the levels of TAT complexes, plasmin- $\alpha 2$ antiplasmin inhibitor-complexes (PIC), and fibrin/ fibrinogen degradation products [120]). In another study in severe sepsis patients, ulinastatin has impressively reduced the incidence of MODS onset by more than 50\% [121]. Furthermore, another serine protease inhibitor, gabexate mesilate, has shown promising results in a rodent endotoxininduced MODS model [122]. Short-term pretreatment has resulted in improved lung, liver, and kidney function; a reduction in both consumptive coagulopathy (determined by thrombelastography) and the inflammatory response; and a reduction in TAT and PAI-1 generation.

Temporary artificial organ replacement or assistance devices to bridge functional organ derangement during fullblown MODS may themselves activate both the complement and coagulation systems, as has been shown in the case of an extracorporeal liver-assist device [123] and lung-assist device [124]. The latest improved extracorporeal oxygenation systems still exhibit a tendency for $\mathrm{C} 3$ consumption and TAT complex formation after a $6-\mathrm{h}$ running time [125]. On the other hand, surface coating of an extracorporeal membrane oxygenation device with nafamostat mesilate has recently led to an increased bleeding risk when compared to standard heparin use [126]. Thus, molecular surface engineering is required for future organ assistance systems and their artificial surfaces in order to prevent cross-activation of the complement and clotting cascades [127]. Furthermore, bedside monitoring of protease activity, including the complement and coagulation systems, is desirable to specifically target and stop the vicious cycle of protease activation and subsequent immune, coagulation, and organ failure.

\section{Pancreatitis}

Although the role of the clotting cascade in the development of acute pancreatitis is well established, the function of complement in this process and the likely crosstalk of both systems, triggered by massive protease release, remain unclear, as indicated in a recent review [128]. In acute pancreatitis, enhanced plasma levels of $\mathrm{C} 3 \mathrm{a}$ and the terminal complement complex (sC5b-9) have been found in humans and are correlated with the severity of the disease [129]. Nevertheless, in the case of acute pancreatitis, pancreas-derived proteases such as trypsin have been proposed to function as the culprit in MODS development [130]. Supporting data has come from 
a meta-analysis showing that ulinastatin can improve indicators of inflammation in acute pancreatitis [131]. Another meta-analysis has shown nafamostat, with its strong coagulation and complement inhibitory profile $[132,133]$ to be effective in post-endoscopic retrograde cholangiopancreatography (ERCP)-induced pancreatitis [134, 135].

In the past, experimental data in acute hemorrhagic pancreatitis in sheep have indicated that the serine protease inhibitor aprotinin (Trasylol@) significantly reduces the pathophysiological consequences of crosstalking systems, such as DIC, granulocyte sequestration, and remote lung vascular permeability [136]. However, translational studies have revealed less convincing results, and therefore, the application of aprotinin has been abandoned for treatment of pancreatitis, especially since the hyperfibrinolytic state in pancreatitis, as major target of the aprotinin therapy, could not be monitored reliably in the pre-thrombelastography era. Currently, aprotinin administration is mainly restricted to complex cardiac surgery (see below) and major orthopedic surgery, where it has been shown to reduce transfusion requirements without increasing the risk of thrombosis [87]. Although mechanistically rational, protease inhibition during pancreatitis to improve clotting and inflammatory complications would benefit greatly from protease monitoring, which is not yet on the horizon.

\section{Cardiac surgery involving cardiopulmonary bypass}

Major cardiac surgery is known to induce a certain degree of systemic inflammation, with cross-activation of the coagulation and complement system, particularly under on-pump conditions [137-141]. Activation of the kallikrein-kinin-system, bradykinin, factor XIIa, and t-PA by cardiopulmonary bypass (CPB) surgery, along with enhanced levels of systemic inflammatory cytokines such as IL-6, IL-8, and TNF, is well established [139]. Simulated extracorporal circulation experiments have suggested that both the contact and complement systems are activated (as evidenced by the formation of C1C1-INH and kallikrein-C1-INH complexes, as well as C5adependent neutrophil elastase generation), all of which can be inhibited by a specific kallikrein blocker [142]. However, in its translation to the clinic, inhibition of the serine protease kallikrein is achieved, for example, by administration of fulldose aprotinin, which is thought to have antifibrinolytic and anti-inflammatory characteristics. This therapeutic approach around CPB operations remains questionable, given the data from single-center studies and also from meta-analyses [143-145]. Several other protease systems, such as cathepsin D [146] and trypsin [147], have been reported to be activated during $\mathrm{CPB}$, and these systems may, in turn, directly cleave key components of the complement cascade [82]. Therefore, trypsin inhibition by ulinastatin had originally seemed a rational therapeutic approach. However, based on a recent metaanalysis of randomized clinical trials, ulinastatin has failed to significantly modulate the cytokine profile but has reduced the duration of mechanical ventilation clinically required [148]. In contrast, another meta-analysis that included CPB patients in China and Japan indicated that ulinastatin not only decreased the need for mechanical ventilation but also improved cytokine profiles [149]. Another therapeutic strategy for inhibiting crosstalking inflammation and coagulation has been to address the potent serine protease FXIIa, which bridges the intrinsic pathway of the clotting system and the classical pathway of the complement system. By inhibiting FXIIa, the antibody $3 \mathrm{~F} 7$ has blocked not only FXIa generation and formation of $\mathrm{C} 3$ activation products but also thrombin, fibrin, and kallikrein activation [141]. In conclusion, 3F7 seems to be equal in potency to the anticoagulatory effects induced by heparin and has therefore been suggested as a safe and promising alternative for heparin in CPB surgery [141].

A critical review of the evidence base for more than 30 different interventions modulating the unquestionable systemic response after CPB has suggested that blockade of C5 and $\mathrm{C} 1 \mathrm{r} / \mathrm{s}$ has several clinical benefits, including myocardial protection [150]. C1-INH, as a pleiotropic agent targeting all the coagulation, complement, and fibrinolytic systems, has been considered ideal for the "multi-hit" model of CPB [150]. In the case of $\mathrm{C} 5$ inhibition, the monoclonal anti-C5 antibody pexelizumab has failed to significantly improve overall survival in CPB patients. However, it conferred a clear survival benefit on a high-risk surgical CPB subgroup throughout the 180-day observation period [151, 152]. Nevertheless, the effects of C5 inhibition on the coagulation system in CPB patients have not been documented and need future detailed consideration. A promising therapeutic strategy for maintaining the terminal complement activation pathway is reflected by a current phase II study in complex cardiac surgery that is using a monoclonal C5a antibody to target the peak IL-6 level as a primary endpoint [151]. Another promising approach in CPB surgery is the modification of the surface coating of the bypass circuit. One study has used a heparin-coated closedcircuit system, which results in lower concentrations of $\mathrm{C} 3 \mathrm{a}$, sC5b-9, t-PA, neutrophil elastase, and IL-8 during the rewarming phase [153]. Overall, coating strategies seem to be essential for modulating the systemic inflammatory response after CPB and may therefore include both the complement and coagulation inhibition that have classically been achieved by heparin coating. Here, specifically addressing the contact system seems to be an interesting clinical goal.

\section{Conclusion}

Under physiological conditions, activation of the cascade systems is under strict control as a result of the high specificity of the generated enzymes and the influence of obligate co-factors, which limit the risk of cross-activation of the systems. 
However, there are many clinical settings that feature massive release of proteolytic enzymes with auxiliary functions that allow them to circumvent this regulation and enable uncontrolled complement-coagulation crosstalk. Furthermore, the presence of such enzymes seems to be of central pathophysiological significance in several diseases. For successful clinical studies, more research efforts are needed to define the critical extent of the protease activity and the exact mechanisms responsible for disease generation and deleterious outcomes. Still, in order to avoid the risks and adverse effects associated with inhibition of central components of the complement and coagulation cascades, specific and targeted interference with downstream proteases exerting de facto harmful functions may prove to be a valuable tool in preventive therapeutic strategies.

Acknowledgments We thank Dr. Deborah McClellan for expert editorial assistance.

This review was supported in part by the DFG CRC1149 A01 and in part by the International Graduate School of Ulm University (IGradU), by providing a Guest Professorship to Bo Nilsson at the Ulm University in 2016, as well as by grants 2016-01060 and 2016-04519 from the Swedish Research Council (VR), the European Community's Seventh Framework Programme under the grant agreement no. 602699 (DIREKT), and faculty grants from the Linnæus University.

Open Access This article is distributed under the terms of the Creative Commons Attribution 4.0 International License (http:// creativecommons.org/licenses/by/4.0/), which permits unrestricted use, distribution, and reproduction in any medium, provided you give appropriate credit to the original author(s) and the source, provide a link to the Creative Commons license, and indicate if changes were made.

\section{References}

1. Vickery HB (1950) The origin of the word protein. Yale J Biol Med 22:387-393

2. Lopez-Otin C, Bond JS (2008) Proteases: multifunctional enzymes in life and disease. J Biol Chem 283:30433-30437

3. Rawlings ND, Barrett AJ (1993) Evolutionary families of peptidases. Biochem J 290(Pt 1):205-218

4. Hedstrom L (2002) Serine protease mechanism and specificity. Chem Rev 102:4501-4524

5. http://www.brenda-enzymes.org/index.php. 2017

6. Fersth A. 1999. Chapters 3A, 3B, and 7B. In Structure and mechanism in protein science. A guide to enzyme catalysis and protein folding, ed. M Julet, pp. 103-11; 218-230. New York: WH Freeman

7. Travis J, Salvesen GS (1983) Human plasma proteinase inhibitors. Annu Rev Biochem 52:655-709

8. Potempa J, Korzus E, Travis J (1994) The serpin superfamily of proteinase inhibitors: structure, function, and regulation. J Biol Chem 269:15957-15960

9. Rehman AA, Ahsan H, Khan FH (2013) alpha-2-Macroglobulin: a physiological guardian. J Cell Physiol 228:1665-1675

10. de Bruijn MH, Fey GH (1985) Human complement component C3: cDNA coding sequence and derived primary structure. Proc Natl Acad Sci U S A 82:708-712

11. Bokisch VA, Muller-Eberhard HJ, Cochrane CG (1969) Isolation of a fragment (C3a) of the third component of human complement containing anaphylatoxin and chemotactic activity and description of an anaphylatoxin inactivator of human serum. J Exp Med 129: $1109-1130$

12. Ekdahl KN, Nilsson UR, Nilsson B (1990) Inhibition of factor I by diisopropylfluorophosphate. Evidence of conformational changes in factor I induced by $\mathrm{C} 3 \mathrm{~b}$ and additional studies on the specificity of factor I. J Immunol 144:4269-4274

13. Ross GD, Lambris JD, Cain JA, Newman SL (1982) Generation of three different fragments of bound $\mathrm{C} 3$ with purified factor I or serum. I. Requirements for factor $\mathrm{H}$ vs CR1 cofactor activity. J Immunol 129:2051-2060

14. Medicus RG, Melamed J, Arnaout MA (1983) Role of human factor I and C3b receptor in the cleavage of surface-bound C3bi molecules. Eur J Immunol 13:465-470

15. Harrison RA, Lachmann PJ (1980) The physiological breakdown of the third component of human complement. Mol Immunol 17: 9-20

16. Medof ME, Iida K, Mold C, Nussenzweig V (1982) Unique role of the complement receptor $\mathrm{CR} 1$ in the degradation of $\mathrm{C} 3 \mathrm{~b}$ associated with immune complexes. J Exp Med 156:1739-1754

17. Davis AE 3rd, Harrison RA, Lachmann PJ (1984) Physiologic inactivation of fluid phase C3b: isolation and structural analysis of C3c, C3d,g (alpha 2D), and C3g. J Immunol 132:1960-1966

18. Ricklin D, Reis E, Mastellos D, Gros P, JD L (2016) Complement component C3 - the "Swiss Army Knife" of innate immunity and host defense. Immunol Rev 274: 33-58

19. Ghebrehiwet B, Muller-Eberhard HJ (1979) C3e: an acidic fragment of human $\mathrm{C} 3$ with leukocytosis-inducing activity. J Immunol 123:616-621

20. Thoman M, Meuth J, Morgan E, Weigle W, TE. H (1984) C3d-K, a kallikrein cleavage fragment of $\mathrm{iC} 3 \mathrm{~b}$ is a potent inhibitor of cellular proliferation. J Immunol 133: 2629-2633

21. Hoeprich PD Jr, Dahinden CA, Lachmann PJ, Davis AE 3rd, Hugli TE (1985) A synthetic nonapeptide corresponding to the $\mathrm{NH} 2$-terminal sequence of $\mathrm{C} 3 \mathrm{~d}-\mathrm{K}$ causes leukocytosis in rabbits. J Biol Chem 260:2597-2600

22. Manning ML, Williams SA, Jelinek CA, Kostova MB, Denmeade SR (2013) Proteolysis of complement factors iC3b and C5 by the serine protease prostate-specific antigen in prostatic fluid and seminal plasma. J Immunol 190:2567-2574

23. Oikonomopoulou K, DeAngelis RA, Chen H, Diamandis EP, Hollenberg MD et al (2013) Induction of complement C3a receptor responses by kallikrein-related peptidase 14. J Immunol 191: 3858-3866

24. Eggertsen G, Hellman U, Lundwall A, Folkersen J, Sjoquist J (1985) Characterization of tryptic fragments of human complement factor C3. Mol Immunol 22:833-841

25. Hellman U, Eggertsen G, Engstrom A, Sjoquist J (1985) Amino acid sequence of the trypsin-generated $\mathrm{C} 3 \mathrm{~d}$ fragment from human complement factor C3. Biochem J 230:353-361

26. Minta JO, Man D, Movat HZ (1977) Kinetic studies on the fragmentation of the third component of complement (C3) by trypsin. J Immunol 118:2192-2198

27. Taylor JC, Crawford IP, Hugli TE (1977) Limited degradation of the third component (C3) of human complement by human leukocyte elastase (HLE): partial characterization of C3 fragments. Biochemistry 16:3390-3396

28. Carlo JR, Spitznagel JK, Studer EJ, Conrad DH, Ruddy S (1981) Cleavage of membrane bound $\mathrm{C} 3 \mathrm{bi}$, an intermediate of the third component of complement, to $\mathrm{C} 3 \mathrm{c}$ and $\mathrm{C} 3 \mathrm{~d}$-like fragments by crude leucocyte lysosomal lysates and purified leucocyte elastase. Immunology 44:381-391

29. Lesavre PH, Hugli TE, Esser AF, Muller-Eberhard HJ (1979) The alternative pathway $\mathrm{C} 3 / \mathrm{C} 5$ convertase: chemical basis of factor $\mathrm{B}$ activation. J Immunol 123:529-534 
30. DiScipio RG, Smith CA, Muller-Eberhard HJ, Hugli TE (1983) The activation of human complement component $\mathrm{C} 5$ by a fluid phase C5 convertase. J Biol Chem 258:10629-10636

31. Pangburn MK, Rawal N (2002) Structure and function of complement C5 convertase enzymes. Biochem Soc Trans 30:1006-1010

32. Huber-Lang M, Sarma JV, Zetoune FS, Rittirsch D, Neff TA et al (2006) Generation of C5a in the absence of C3: a new complement activation pathway. Nat Med 12:682-687

33. Amara U, Flierl MA, Rittirsch D, Klos A, Chen H et al (2010) Molecular intercommunication between the complement and coagulation systems. J Immunol 185:5628-5636

34. Foley JH, Walton BL, Aleman MM, O'Byrne AM, Lei V et al (2016) Complement activation in arterial and venous thrombosis is mediated by plasmin. EBioMedicine 5:175-182

35. Krisinger M, Goebeler V, Lu Z, Meixner S, Myles T et al (2012) Thrombin generates previously unidentified $\mathrm{C} 5$ products that support the terminal complement activation pathway. Blood 120: 1717-1725

36. Wetsel RA, Kolb WP (1983) Expression of C5a-like biological activities by the fifth component of human complement (C5) upon limited digestion with noncomplement enzymes without release of polypeptide fragments. J Exp Med 157:2029-2048

37. Fredslund F, Laursen N, Roversi P, Jenner L, Oliveira $\mathrm{C}$ et al (2008) Structure of and influence of a tick complement inhibitor on human complement component 5. Nat Immunol 9:753-760

38. Lim YP, Bendelja K, Opal SM, Siryaporn E, Hixson DC et al (2003) Correlation between mortality and the levels of inter-alpha inhibitors in the plasma of patients with severe sepsis. J Infect Dis 188:919-926

39. Choi Q, Hong KH, Kim JE, Kim HK (2014) Changes in plasma levels of natural anticoagulants in disseminated intravascular coagulation: high prognostic value of antithrombin and protein $\mathrm{C}$ in patients with underlying sepsis or severe infection. Ann Lab Med 34:85-91

40. Castiblanco-Valencia MM, Fraga TR, Pagotto AH, Serrano SM, Abreu PA et al (2016) Plasmin cleaves fibrinogen and the human complement proteins $\mathrm{C} 3 \mathrm{~b}$ and $\mathrm{C} 5$ in the presence of Leptospira interrogans proteins: a new role of LigA and LigB in invasion and complement immune evasion. Immunobiology 221:679-689

41. Bokisch VA, Müller-Eberhard H (1970) Anaphylatoxin inactivator of human plasma: its isolation and characterization as a carboxy-peptidase. J Clin Invest 49:2427-2436

42. Reis ES, Chen H, Sfyroera G, Monk PN, Kohl J et al (2012) C5a receptor-dependent cell activation by physiological concentrations of desarginated C5a: insights from a novel label-free cellular assay. J Immunol 189:4797-4805

43. Leung LL, Myles T, Nishimura T, Song JJ, Robinson WH (2008) Regulation of tissue inflammation by thrombin-activatable carboxypeptidase B (or TAFI). Mol Immunol 45:4080-4083

44. Wiger D, Natvig J (1972) The effect of enzyme digestion on the antigenicity and biologic activity of Clq. J Immunol 109:933-939

45. Knobel HR, Heusser C, Rodrick ML, Isliker H (1974) Enzymatic digestion of the first component of human complement (C1q). J Immunol 112:2094-2101

46. Reid KB (1976) Isolation, by partial pepsin digestion, of the three collagen-like regions present in subcomponent Clq of the first component of human complement. Biochem J 155:5-17

47. Wolf U, Bauer D, Traub WH (1991) Collagenase of Clostridium perfringens type A: degradation of human complement component C1q. Zentralbl Bakteriol 276:27-35

48. Menzel JE, Scherak O, Kolarz G, Gamerith F, Youngchaiyud U (1991) A method to differentiate between anti-C1q antibodies and C1q-binding immune complexes using collagenase-digested solid phase C1q. J Immunol Methods 138:165-171
49. Mori Y, Ueda E, Takeuchi T, Taniuchi S, Koyama J (1980) Proteolytic cleavage of an activated subcomponent of the first component of rabbit complement, C1s. J Biochem 87:1757-1763

50. Okada F, Takahashi K, Nagasawa S, Koyama J (1987) Variations in the enzymatic properties of human complement subcomponent C1s by treatment with human plasma kallikrein. J Biochem 102: 939-946

51. Ziccardi R, Cooper N (1976) Activation of C1r by proteolytic cleavage. J Immunol 116:504-509

52. Ghebrehiwet B, Randazzo BP, Dunn JT, Silverberg M, Kaplan AP (1983) Mechanisms of activation of the classical pathway of complement by Hageman factor fragment. J Clin Invest 71:1450-1456

53. Bolotin C, Morris S, Tack B, Prahl J (1977) Purification and structural analysis of the fourth component of human complement. Biochemistry 16:2008-2015

54. Kerr MA (1979) Limited proteolysis of complement components C2 and factor B. Structural analogy and limited sequence homology. Biochem J 183:615-622

55. Ngan BY, Minta JO (1981) Proteolysis of C2 and factor B: analyses of cleavage products by one- and two- dimensional peptide mapping. Mol Immunol 18:1035-1047

56. Sinha VK, Sharma OP, Kumar MS (2017) Insight into the intermolecular recognition mechanism involved in complement component 4 activation through serine protease-trypsin. J Biomol Struct Dyn: 1-15

57. Chen Q, Xue H, Chen M, Gao F, Xu J et al (2014) High serum trypsin levels and the $-409 \mathrm{~T} / \mathrm{T}$ genotype of PRSS1 gene are susceptible to neonatal sepsis. Inflammation 37:1751-1756

58. Duswald KH, Jochum M, Schramm W, Fritz H (1985) Released granulocytic elastase: an indicator of pathobiochemical alterations in septicemia after abdominal surgery. Surgery 98:892-899

59. Muhl D, Nagy B, Woth G, Falusi B, Bogar L et al (2011) Dynamic changes of matrix metalloproteinases and their tissue inhibitors in severe sepsis. J Crit Care 26:550-555

60. Melish ME, Glasgow LA (1970) The staphylococcal scalded-skin syndrome. N Engl J Med 282:1114-1119

61. Dancer SJ, Garratt R, Saldanha J, Jhoti H, Evans R (1990) The epidermolytic toxins are serine proteases. FEBS Lett 268:129-132

62. Altshuler AE, Penn AH, Yang JA, Kim GR, Schmid-Schonbein GW (2012) Protease activity increases in plasma, peritoneal fluid, and vital organs after hemorrhagic shock in rats. PLoS One 7: e32672

63. Schmid-Schonbein GW, Chang M (2014) The autodigestion hypothesis for shock and multi-organ failure. Ann Biomed Eng 42: 405-414

64. Deby-Dupont G, Haas M, Pincemail J, Braun M, Lamy M et al (1984) Immunoreactive trypsin in the adult respiratory distress syndrome. Intensive Care Med 10:7-12

65. Bhatia R, Dent C, Topley N, Pallister I (2006) Neutrophil priming for elastase release in adult blunt trauma patients. J Trauma 60 : 590-596

66. Ji SC, Pan YT, Lu QY, Sun ZY, Liu YZ (2014) Screening of differentially expressed genes between multiple trauma patients with and without sepsis. Genet Mol Res 13:1855-1864

67. Kanse SM, Gallenmueller A, Zeerleder S, Stephan F, Rannou O et al (2012) Factor VII-activating protease is activated in multiple trauma patients and generates anaphylatoxin C5a. J Immunol 188: 2858-2865

68. Howes J, Richardson V, Smith K, Schroeder V, Somani R et al (2012) Complement C3 is a novel plasma clot component with anti-fibrinolytic properties. Diab Vasc Dis Res 9:216-225

69. Turk B (2006) Targeting proteases: successes, failures and future prospects. Nat Rev Drug Discov 5:785-799

70. Kvasnicka J, Rezac J, Svejda J, Duchkova H, Kaze F et al (1979) Disseminated intravascular coagulation associated with toxic epidermal necrolysis (Lyell's syndrome). Br J Dermatol 100:551-558 
71. Su SC, Chung WH (2014) Cytotoxic proteins and therapeutic targets in severe cutaneous adverse reactions. Toxins (Basel) 6: 194-210

72. Perl M, Denk S, Kalbitz M, Huber-Lang M (2012) Granzyme B: a new crossroad of complement and apoptosis. Adv Exp Med Biol 946:135-146

73. Inamo Y, Okubo T, Wada M, Fuchigami S, Hashimoto K et al (2002) Intravenous ulinastatin therapy for Stevens-Johnson syndrome and toxic epidermal necrolysis in pediatric patients. Three case reports. Int Arch Allergy Immunol 127:89-94

74. Iwatsuki K, Yamasaki O, Morizane S, Oono T (2006) Staphylococcal cutaneous infections: invasion, evasion and aggression. J Dermatol Sci 42:203-214

75. Lambris JD, Ricklin D, Geisbrecht BV (2008) Complement evasion by human pathogens. Nat Rev Microbiol 6:132-142

76. Amagai M (2010) Autoimmune and infectious skin diseases that target desmogleins. Proc Jpn Acad Ser B Phys Biol Sci 86:524 537

77. Burk A, Martin M, Flierl M, Rittirsch D, Helm M et al (2012) Early complementopathy after multiple injuries in humans. Shock 37:348-354

78. Hecke F, Schmidt U, Kola A, Bautsch W, Klos A et al (1997) Circulating complement proteins in multiple trauma patientscorrelation with injury severity, development of sepsis, and outcome. Crit Care Med 25:2015-2024

79. Helling H, Stephan B, Pindur G (2015) Coagulation and complement system in critically ill patients. Clin Hemorheol Microcirc 61:185-193

80. Hoth JJ, Wells JD, Jones SE, Yoza BK, McCall CE (2014) Complement mediates a primed inflammatory response after traumatic lung injury. J Trauma Acute Care Surg 76:601-609

81. Buzza MS, Dyson JM, Choi H, Gardiner EE, Andrews RK et al (2008) Antihemostatic activity of human granzyme B mediated by cleavage of von Willebrand factor. J Biol Chem 283:22498-22504

82. Huber-Lang M, Denk S, Fulda S, Erler E, Kalbitz M et al (2012) Cathepsin D is released after severe tissue trauma in vivo and is capable of generating C5a in vitro. Mol Immunol 50:60-65

83. Hock CE, Lefer AM (1985) Beneficial effects of a neutral protease inhibitor in traumatic shock. Pharmacol Res Commun 17:217226

84. Huo J, Zhu XL, Ma R, Dong HL, Su BX (2016) GAPDH/Siah1 cascade is involved in traumatic spinal cord injury and could be attenuated by sivelestat sodium. Neuroscience 330:171-180

85. Park KH, Lee KH, Kim H, Hwang SO (2010) The antiinflammatory effects of ulinastatin in trauma patients with hemorrhagic shock. J Korean Med Sci 25:128-134

86. Heeres M, Visser T, van Wessem KJ, Koenderman AH, Strengers $\mathrm{PF}$ et al (2011) The effect of C1-esterase inhibitor on systemic inflammation in trauma patients with a femur fracture- the CAESAR study: study protocol for a randomized controlled trial. Trials 12:223

87. Huang F, Zhao Q, Guo C, Ma G, Wang Q et al (2014) Use of aprotinin to reduce blood loss and transfusion in major orthopedic surgery: a meta-analysis. Transfus Apher Sci 51:152-161

88. Kim HD, Malinoski DJ, Borazjani B, Patel MS, Chen J et al (2010) Inhibition of intraluminal pancreatic enzymes with nafamostat mesilate improves clinical outcomes after hemorrhagic shock in swine. J Trauma 68:1078-1083

89. Hazelzet JA, de Groot R, van Mierlo G, Joosten KF, van der Voort E et al (1998) Complement activation in relation to capillary leakage in children with septic shock and purpura. Infect Immun 66: $5350-5356$

90. Unnewehr H, Rittirsch D, Sarma J, Zetoune F, Flierl M et al (2013) Changes and regulation of the $\mathrm{C} 5$ a receptor on neutrophils during septic shock in humans. J Immunol J Immunol 190:4215-4225
91. Boermeester MA, van Leeuwen PA, Coyle SM, Wolbink GJ, Hack CE et al (1995) Interleukin-1 blockade attenuates mediator release and dysregulation of the hemostatic mechanism during human sepsis. Arch Surg 130:739-748

92. Lupu F, Keshari RS, Lambris JD, Coggeshall KM (2014) Crosstalk between the coagulation and complement systems in sepsis. Thromb Res 133(Suppl 1):S28-S31

93. Ren J, Zhao Y, Yuan Y, Han G, Li W et al (2012) Complement depletion deteriorates clinical outcomes of severe abdominal sepsis: a conspirator of infection and coagulopathy in crime? PLoS One 7:e47095

94. Gando S, Kameue T, Matsuda N, Hayakawa M, Morimoto Y et al (2003) Imbalances between the levels of tissue factor and tissue factor pathway inhibitor in ARDS patients. Thromb Res 109:119 124

95. de Jong HK, Koh GC, Bulder I, Stephan F, Wiersinga WJ et al (2015) Diabetes-independent increase of factor VII-activating protease activation in patients with Gram-negative sepsis (melioidosis). J Thromb Haemost 13:41-46

96. Nielsen JD (1998) The effect of antithrombin on the systemic inflammatory response in disseminated intravascular coagulation. Blood Coagul Fibrinolysis 9(Suppl 3):S11-S15

97. Fourrier F, Jourdain M, Tournoys A (2000) Clinical trial results with antithrombin III in sepsis. Crit Care Med 28:S38-S43

98. Inthorn D, Hoffmann JN, Hartl WH, Muhlbayer D, Jochum M (1998) Effect of antithrombin III supplementation on inflammatory response in patients with severe sepsis. Shock 10:90-96

99. Papareddy P, Kalle M, Bhongir RK, Morgelin M, Malmsten M et al (2014) Antimicrobial effects of helix D-derived peptides of human antithrombin III. J Biol Chem 289:29790-29800

100. Tsuboko Y, Takeda S, Mii S, Nakazato K, Tanaka K et al (2012) Clinical evaluation of sivelestat for acute lung injury/acute respiratory distress syndrome following surgery for abdominal sepsis. Drug Des Devel Ther 6:273-278

101. Nishina K, Mikawa K, Takao Y, Maekawa N, Shiga M et al (1997) ONO-5046, an elastase inhibitor, attenuates endotoxin-induced acute lung injury in rabbits. Anesth Analg 84:1097-1103

102. Laudes IJ, Chu JC, Sikranth S, Huber-Lang M, Guo RF et al (2002) Anti-c5a ameliorates coagulation/fibrinolytic protein changes in a rat model of sepsis. Am J Pathol 160:1867-1875

103. Takazono T, Nakamura S, Imamura Y, Yoshioka S, Miyazaki T et al (2014) A retrospective comparative study of recombinant human thrombomodulin and gabexate mesilate in sepsis-induced disseminated intravascular coagulation patients. J Infect Chemother 20:484-488

104. Linder A, Russell JA (2014) An exciting candidate therapy for sepsis: ulinastatin, a urinary protease inhibitor. Intensive Care Med 40:1164-1167

105. Han D, Shang W, Wang G, Sun L, Zhang Y et al (2015) Ulinastatin- and thymosin alpha1-based immunomodulatory strategy for sepsis: a meta-analysis. Int Immunopharmacol 29:377382

106. Wang FY, Fang B, Qiang XH, Yu TO, Zhong JR et al (2016) The efficacy and immunomodulatory effects of ulinastatin and thymosin alpha1 for sepsis: a systematic review and meta-analysis. Biomed Res Int 2016:9508493

107. Feng Z, Shi Q, Fan Y, Wang Q, Yin W (2016) Ulinastatin and/or thymosin alpha1 for severe sepsis: a systematic review and metaanalysis. J Trauma Acute Care Surg 80:335-340

108. Lissauer ME, Johnson SB, Siuzdak G, Bochicchio G, Whiteford C et al (2007) Coagulation and complement protein differences between septic and uninfected systemic inflammatory response syndrome patients. J Trauma 62:1082-1094

109. Hotchkiss RS, Swanson PE, Freeman BD, Tinsley KW, Cobb JP et al (1999) Apoptotic cell death in patients with sepsis, shock, and multiple organ dysfunction. Crit Care Med 27:1230-1251 
110. Ren Y, He QY, Fan J, Jones B, Zhou Y et al (2004) The use of proteomics in the discovery of serum biomarkers from patients with severe acute respiratory syndrome. Proteomics 4:3477-3484

111. Leng YX, Yang SG, Song YH, Zhu X, Yao GQ (2014) Ulinastatin for acute lung injury and acute respiratory distress syndrome: a systematic review and meta-analysis. World J Crit Care Med 3:34-41

112. Rensing H, Bauer M (2001) Multiple organ failure. Mechanisms, clinical manifestations and treatment strategies. Anaesthesist 50: 819-841

113. Huber-Lang M, Sarma VJ, Lu KT, McGuire SR, Padgaonkar VA et al (2001) Role of C5a in multiorgan failure during sepsis. J Immunol 166:1193-1199

114. Rittirsch D, Redl H, Huber-Lang M (2012) Role of complement in multiorgan failure. Clin Dev Immunol 2012:962927

115. Keel M, Trentz O (2005) Pathophysiology of polytrauma. Injury 36:691-709

116. Silasi-Mansat R, Zhu H, Popescu NI, Peer G, Sfyroera G et al (2010) Complement inhibition decreases the procoagulant response and confers organ protection in a baboon model of Escherichia coli sepsis. Blood 116:1002-1010

117. Rittirsch D, Schoenborn V, Lindig S, Wanner E, Sprengel K et al (2015) Improvement of prognostic performance in severely injured patients by integrated clinico-transcriptomics: a translational approach. Crit Care 19:414

118. Atal SS, Atal S (2016) Ulinastatin - a newer potential therapeutic option for multiple organ dysfunction syndrome. J Basic Clin Physiol Pharmacol 27:91-99

119. Kang WS, Kim DK, Yoon TG, Kim TY, Kim SH (2011) In vitro effects of ulinastatin on blood coagulation using thromboelastography. Minerva Med 102:109-113

120. Nishiyama T, Yokoyama T, Yamashita K (2006) Effects of a protease inhibitor, ulinastatin, on coagulation and fibrinolysis in abdominal surgery. J Anesth 20:179-182

121. Karnad DR, Bhadade R, Verma PK, Moulick ND, Daga MK et al (2014) Intravenous administration of ulinastatin (human urinary trypsin inhibitor) in severe sepsis: a multicenter randomized controlled study. Intensive Care Med 40:830-838

122. Tsai HJ, Ding C, Tsao CM, Liao MH, Ka SM et al (2015) Effects of gabexate mesilate on coagulopathy and organ dysfunction in rats with endotoxemia: a potential use of thrombelastography in endotoxin-induced sepsis. Blood Coagul Fibrinolysis 26:175-184

123. Hughes RD, Nicolaou N, Langley PG, Ellis AJ, Wendon JA et al (1998) Plasma cytokine levels and coagulation and complement activation during use of the extracorporeal liver assist device in acute liver failure. Artif Organs 22:854-858

124. Peek GJ, Firmin RK (1999) The inflammatory and coagulative response to prolonged extracorporeal membrane oxygenation. ASAIO J 45:250-263

125. Stang K, Borchardt R, Neumann B, Kurz J, Stoppelkamp S et al (2015) First in vivo results of a novel pediatric oxygenator with an integrated pulsatile pump. ASAIO J 61:574-582

126. Lim JY, Kim JB, Choo SJ, Chung CH, Lee JW et al (2016) Anticoagulation during extracorporeal membrane oxygenation; nafamostat mesilate versus heparin. Ann Thorac Surg 102:534539

127. Wiegner R, Chakraborty S, Huber-Lang M (2016) Complementcoagulation crosstalk on cellular and artificial surfaces. Immunobiology 221:1073-1079

128. Bettac L, Denk S, Seufferlein T, Huber-Lang M (2017) Complement in pancreatic disease-perpetrator or savior? Front Immunol 8:15

129. Gloor B, Stahel PF, Muller CA, Schmidt OI, Buchler MW et al (2003) Predictive value of complement activation fragments C3a and sC5b-9 for development of severe disease in patients with acute pancreatitis. Scand J Gastroenterol 38:1078-1082
130. Sha H, Ma Q, Jha RK (2009) Trypsin is the culprit of multiple organ injury with severe acute pancreatitis. Med Hypotheses 72: 180-182

131. Wang LZ, Luo MY, Zhang JS, Ge FG, Chen JL et al (2016) Effect of ulinastatin on serum inflammatory factors in Asian patients with acute pancreatitis before and after treatment: a meta-analysis. Int J Clin Pharmacol Ther 54:890-898

132. Ueda N, Midorikawa A, Ino Y, Oda M, Nakamura K et al (2000) Inhibitory effects of newly synthesized active center-directed trypsin-like serine protease inhibitors on the complement system. Inflamm Res 49:42-46

133. Keck T, Balcom JH, Antoniu BA, Lewandrowski K, Warshaw AL et al (2001) Regional effects of nafamostat, a novel potent protease and complement inhibitor, on severe necrotizing pancreatitis. Surgery 130:175-181

134. Yu G, Li S, Wan R, Wang X, Hu G (2015) Nafamostat mesilate for prevention of post-ERCP pancreatitis: a meta-analysis of prospective, randomized, controlled trials. Pancreas 44:561-569

135. Wang J, Su J, Lu Y, Zhou H, Gong B (2014) A randomized control study to investigate the application of Ulinastatin-containing contrast medium to prevent post-ERCP pancreatitis. HepatoGastroenterology 61:2391-2394

136. Garcia-Szabo RR, Malik AB (1984) Pancreatitis-induced increase in lung vascular permeability. Protective effect of Trasylol. Am Rev Respir Dis 129:580-583

137. Butler J, Rocker GM, Westaby S (1993) Inflammatory response to cardiopulmonary bypass. Ann Thorac Surg 55:552-559

138. Seghaye MC, Duchateau J, Grabitz RG, Jablonka K, Wenzl T et al (1996) Influence of low-dose aprotinin on the inflammatory reaction due to cardiopulmonary bypass in children. Ann Thorac Surg 61:1205-1211

139. Sniecinski RM, Chandler WL (2011) Activation of the hemostatic system during cardiopulmonary bypass. Anesth Analg 113:1319 1333

140. Pagowska-Klimek I, Swierzko AS, Michalski M, Glowacka E, Szala-Pozdziej A et al (2016) Activation of the lectin pathway of complement by cardiopulmonary bypass contributes to the development of systemic inflammatory response syndrome after paediatric cardiac surgery. Clin Exp Immunol 184:257-263

141. Dobrovolskaia MA, McNeil SE (2015) Safe anticoagulation when heart and lungs are "on vacation". Ann Transl Med 3:S11

142. Wachtfogel YT, Hack CE, Nuijens JH, Kettner C, Reilly TM et al (1995) Selective kallikrein inhibitors alter human neutrophil elastase release during extracorporeal circulation. Am J Phys 268: H1352-H1357

143. Brown JR, Toler AW, Kramer RS, Landis RC (2009) Antiinflammatory effect of aprotinin: a meta-analysis. J Extra Corpor Technol 41:79-86

144. Cicekcioglu F, Cagli K, Emir M, Topbas M, Catav Z et al (2006) Effects of minimal dose aprotinin on blood loss and fibrinolytic system-complement activation in coronary artery bypass grafting surgery. J Card Surg 21:336-341

145. Segal H, Sheikh S, Kallis P, Cottam S, Beard C et al (1998) Complement activation during major surgery: the effect of extracorporeal circuits and high-dose aprotinin. J Cardiothorac Vasc Anesth 12:542-547

146. Starling JR, Murray GF, Adams K, Painter JC, Johnson G Jr (1975) Erythrocyte filterability and lysosomal enzymes in patients requiring cardiopulmonary bypass. Surgery $77: 562-568$

147. Nys M, Venneman I, Deby-Dupont G, Preiser JC, Vanbelle S et al (2007) Pancreatic cellular injury after cardiac surgery with cardiopulmonary bypass: frequency, time course and risk factors. Shock 27:474-481

148. He S, Lin K, Ma R, Xu R, Xiao Y (2015) Effect of the urinary tryptin inhibitor ulinastatin on cardiopulmonary bypass-related 
inflammatory response and clinical outcomes: a meta-analysis of randomized controlled trials. Clin Ther 37:643-653

149. Zhang Y, Zeng Z, Cao Y, Du X, Wan Z (2014) Effect of urinary protease inhibitor (ulinastatin) on cardiopulmonary bypass: a meta-analysis for China and Japan. PLoS One 9:e113973

150. Landis RC, Brown JR, Fitzgerald D, Likosky DS, ShoreLesserson L et al (2014) Attenuating the systemic inflammatory response to adult cardiopulmonary bypass: a critical review of the evidence base. J Extra Corpor Technol 46:197-211

151. https://clinicaltrials.gov/show/NCT00088179

152. Smith PK, Shernan SK, Chen JC, Carrier M, Verrier ED et al (2011) Effects of C5 complement inhibitor pexelizumab on outcome in high-risk coronary artery bypass grafting: combined results from the PRIMO-CABG I and II trials. J Thorac Cardiovasc Surg 142:89-98
153. Lindholm L, Westerberg M, Bengtsson A, Ekroth R, Jensen E et al (2004) A closed perfusion system with heparin coating and centrifugal pump improves cardiopulmonary bypass biocompatibility in elderly patients. Ann Thorac Surg 78:2131-2138

154. Maison CM, Villiers CL, Colomb MG (1991) Proteolysis of C3 on U937 cell plasma membranes. Purification of cathepsin G J Immunol 147:921-926

155. Lipitsa T, Naukkarinen A, Laitala J, Harvima IT (2016) Complement $\mathrm{C} 3$ is expressed by mast cells in cutaneous vasculitis and is degraded by chymase. Arch Dermatol Res 308:575-584

156. Fukuoka Y, Xia HZ, Sanchez-Munoz LB, Dellinger AL, Escribano L et al (2008) Generation of anaphylatoxins by human beta-tryptase from C3, C4, and C5. J Immunol 180:6307-6316 